\title{
KUALITAS JERAMI SORGUM MANIS VARIETAS NUMBU DENGAN PEMBERIAN PUPUK SUMBER FOSFAT YANG BERBEDA
}

(Quality of Sweet Sorghum Varieties Numbu with Different Phosphate Fertilizer Sources)

\author{
Winata, N.A.S.H. ${ }^{1}$, Lukiwati, D.R. ${ }^{2}$, dan Purbajanti, E.D. ${ }^{2}$ \\ 1) Mahasiswa Pasca Sarjana Fakultas Peternakan Dan Pertanian Universitas Diponegoro \\ Kampus drh. Soejono Koesoemowardojo Tembalang Semarang 50275 \\ email: hendrawinata46@gmail.com \\ ${ }^{2)}$ Fakultas Peternakan Dan Pertanian Universitas Diponegoro \\ Kampus drh. Soejono Koesoemowardojo Tembalang Semarang 50275
}

Diterima: 13 Mei 2014 Disetujui: 28 Juni 2015

\begin{abstract}
Sorghum is a crop that almost can be used, example grain sorghum used as poultry feed, straw as ruminant feed. Price SP-36 expensive cause problems in plant fertilization phosphate source. Phosphoric acid soluble nature has properties that need special method to increase the solubility in water. Manure solvent for the decomposition of phosphate rock produces organic acids. Charcoal used as amandement, because it's improve soil physical. The study was conducted from March to August 2013 in crop land collection Plant and Food Science Laboratory Faculty of Animal Husbandry and Agriculture, Diponegoro University. Research materials seeds of numbu sweet sorghum SEAMEO BIOTROP Bogor, area $220 \mathrm{~m}^{2}$ consists of 30 plots with plot size of $3 \mathrm{~m} \times 2 \mathrm{~m}$ with spacing of $50 \mathrm{~cm} \times 25 \mathrm{~cm}$ and distance between plots of $0.5 \mathrm{~m}$, plant number 42, manure and manure "plus" 20 tons / ha, charcoal 8 tons / ha, $66 \mathrm{~kg}$ rock phosphate P/ha, SP-36 $66 \mathrm{Kg} P / \mathrm{ha}$, microbial starter stardec. The experimental design this study was a randomized block design (RBD) with 3 replications as group. Treatment consisted of $T 0=$ Control, $T 1=S P 36, T 2=$ Rock Phosphate (RP), T3 = Manure, T4 = Manure "Plus", T5 = Charcoal, T6 = Rock Phosphate + Charcoal, $T 7=$ SP $36+$ Charcoal, $T 8=$ Manure + Charcoal, $T 9=$ Manure "Plus" + Charcoal. Treatment SP36, RP, manure, manure"plus" with or without charcoal is not able to increase the levels of dry matter, crude protein and crude fiber, but is able to increase the levels of phosphate sorghum straw.
\end{abstract}

Keyword: Sorghum, quality, phosphate, rock phosphate.

\begin{abstract}
ABSTRAK
Sorgum merupakan tanaman yang hampir semua bagian dapat dimanfaatkan, misalnya pada biji sorgum dapat dijadikan pakan unggas, sedangkan hasil samping seperti jerami dapat dijadikan sebagai pakan ternak ruminansia. Harga SP-36 yang mahal menyebabkan masalah dalam pemupukan tanaman utamnya sumber fosfat. Fosfat alam memiliki sifat larut asam sehingga perlu dilakuakan metode khusus untuk meningkatkan kelarutan dalam air. Pupuk kandang dapat dimanfaatkan sebagai pelarut batuan fosfat karena proses dekomposisi menghasilkan asam-asam organik. Arang tempurung kelapa digunakan sebagai pembenah tanah, karena sifatnya yang memperbaiki sifat fisik tanah. Penelitian dilaksanakan mulai bulan Maret sampai Agustus 2013 di lahan tanaman koleksi
\end{abstract}


Laboratorium Ilmu Tanaman dan Makanan Ternak Fakultas Peternakan dan Pertanian Universitas Diponegoro Semarang. Materi penelitian yang akan digunakan adalah biji sorgum manis varietas numbu dari SEAMEO BIOTROP Bogor, luas lahan yang digunakan $220 \mathrm{~m}^{2}$ terdiri dari 30 petak dengan ukuran petak $3 \mathrm{~m} \times 2 \mathrm{~m}$ dengan jarak tanam $50 \mathrm{~cm} \times$ $25 \mathrm{~cm}$ dan jarak antar petak 0,5 m, jumlah tanaman 42, pupuk kandang dan pupuk kandang "plus" 20 ton/ha, dosis arang tempurung kelapa 8 ton/ha, batuan fosfat dosis $66 \mathrm{~kg} \mathrm{P} / \mathrm{ha}$, dosis SP-36 $66 \mathrm{kgP} / \mathrm{ha}$, starter mikroba Stardec. Rancangan percobaan yang digunakan pada penelitian ini adalah Rancangan Acak Kelompok (RAK) dengan 3 ulangan sebagai kelompok. Perlakuan penelitian terdiri dari T0 $=$ Kontrol, T1 $=$ SP 36, T2 $=$ Batuan Fosfat, T3= Pupuk Kandang, T4= Pupuk Kandang "Plus", T5= Arang, T6= Batuan Fosfat + Arang, T7= SP $36+$ Arang, T8= Pupuk Kandang + Arang, T9= Pupuk Kandang "Plus" + Arang. Pupuk kandang dan pupuk kandang "plus" 20 ton/ha, dosis arang tempurung kelapa 8 ton/ha, batuan fosfat dosis $66 \mathrm{~kg} \mathrm{P} / \mathrm{ha}$, dosis SP-36 $66 \mathrm{kgP} / \mathrm{ha}$, pupuk dasar Amunium Sulfat $100 \mathrm{kgN} / \mathrm{ha}$, dan $\mathrm{KCl}$ 70kgK/ha. Perlakuan SP36, BP, pukan, pukan"plus" dengan atau tanpa arang tidak mampu meningkatkan kadar BK, PK dan SK, tetapi mampu meningkatkan kadar fosfat jerami sorgum.

Kata kunci: Sorgum, kualitas, fosfat, P alam.

\section{PENDAHULUAN}

Tanaman sorgum mempunyai daya adaptasi yang luas, toleran kekeringan, dan relatif lebih tahan terhadap hama dan penyakit sehingga sesuai dikembangkan di daerah iklim kering (Pabbage, 2005). Biji sorgum dimanfaatkan sebagai pengganti jagung, sedangkan hijauan dan batang sorgum digunakan untuk pakan ternak ruminansia (Soeranto et al., 1996). Varietas Numbu mempunyai ketahanan yang lebih tinggi dibanding Varietas Kawali dan Genjah, yang dapat dilihat dari nilai kecepatan kecambah, daya kecambah, tinggi tajuk, dan panjang akar yang dihasilkan (Samanhudi, 2010)

Penggunaan pupuk P-alam sebagai sumber fosfat memiliki prospek yang cukup baik karena mudah larut dalam kondisi masam, murah dan proses pelepasan $\mathrm{P}$ secara lambat (slow release) (Tuherkih dan Dariah, 2009). P-alam dapat dijadikan sumber pupuk $\mathrm{P}$ yang efektif dan murah serta dapat meningkatkan produktivitas tanah dan tanaman (Hartatik, 2011).

Pupuk kandang merupakan hasil limbah dari sisa pakan ternak dann kotoran ternak yang telah mengalami dekomposisi. Pemberian pupuk kandang selain dapat menambah tersedianya unsur hara, juga dapat memperbaiki sifat fisik tanah (Ari, 2007). Penelitian tentang pupuk kandang, bahwa pemberian pupuk kandang pada tanah masam dapat memperbaiki drainase, porositas, permeabilitas, dan pori air tersedia (Shanti, 2009). Proses dekomposisi pada pembuatan pupuk kandang menghasailkan asam-asam organik yang dapat melarutkan $\mathrm{P}$ pada batuan fosfat menjadi tersedia sehingga pemberian pada tanaman akan mudah terserap (Soelaeman, 2007).

Arang aktif merupakan suatu bahan berupa karbon amorf yang sebagian besar terdiri atas atom karbon bebas (Lempang et al., 2011). Arang mempunyai potensi untuk dikembangkan sebagai penyerap dan pelepas unsur hara (pupuk) pada tanah karena memiliki luas permukaan yang besar dan hampir sama dengan koloid tanah (Nyoman dan Sri, 2007). Keunggulan arang aktif mempunyai daya serap (adsorpsi) yang tinggi terhadap bahan yang berbentuk larutan atau uap, dapat memperbaiki $\mathrm{pH}$ tanah, mempermudah aerasi tanah, 
membatu peningkatan jumlah populasi mikroba tanah dan dapat merangsang pembentukan akar tanaman (Rostiwati et al., 2008).

Hipotesis penelitian adalah pemberian pukan"plus" dengan atau tanpa arang mampu meningkatkan kualitas jerami sorgum.

\section{MATERI DAN METODE}

Penelitian dilaksanakan mulai bulan Maret sampai Agustus 2013 di lahan tanaman koleksi Laboratorium Ilmu Tanaman dan Makanan Ternak Fakultas Peternakan dan Pertanian Universitas Diponegoro Semarang. Penelitian dilakukan dengan 2 kali pemotongan, yakni panen 1 dan panen 2 .

\section{Materi}

Materi penelitian yang akan digunakan adalah benih sorgum manis dari SEAMEO BIOTROP Bogor, luas lahan yang digunakan $220 \mathrm{~m}^{2}$ terdiri dari 30 petak dengan ukuran petak $3 \mathrm{~m}$ x $2 \mathrm{~m}$ dengan jarak tanam $50 \mathrm{~cm} \times 25 \mathrm{~cm}$ dan jarak antar petak 0,5 m, jumlah tanaman 42, pupuk kandang dan pupuk kandang "plus" 20 ton/ha, dosis arang tempurung kelapa 8 ton/ha, batuan fosfat dosis $66 \mathrm{~kg} \mathrm{P} / \mathrm{ha}$, dosis SP-36 $66 \mathrm{kgP} / \mathrm{ha}$, starter mikroba Stardec, pupuk dasar Amunium Sulfat $100 \mathrm{kgN} / \mathrm{ha}$, dan $\mathrm{KCl} 70 \mathrm{kgK} / \mathrm{ha}$. Peralatan yang digunakan adalah cangkul, timbangan, gunting, amplop sample, alat ukur panjang, alat tulis, kertas label, plastik warna hitam, oven, sperktrofotometer dan eksikator.

\section{Metode}

Rancangan percobaan yang digunakan pada penelitian adalah Rancangan Acak Kelompok (RAK) dengan 3 ulangan sebagai kelompok. Penggunaan rancangan diharapkan mampu mengatisipasi bila lahan yang digunakan mengalami perbedaan kesuburan tanah. Perlakuan penelitian terdiri dari $\mathrm{T} 0=$ Kontrol, T1= SP 36, T2= Batuan Fosfat, T3= Pupuk Kandang, T4= Pupuk Kandang "Plus", T5= Arang, T6= Batuan Fosfat + Arang, T7= SP $36+$ Arang, T8= Pupuk Kandang + Arang, T9= Pupuk Kandang "Plus" + Arang. Pupuk kandang dan pupuk kandang "plus" 20 ton/ha, dosis arang tempurung kelapa 8 ton/ha, batuan fosfat dosis $66 \mathrm{~kg} \mathrm{P} / \mathrm{ha}$, dosis SP-36 $66 \mathrm{kgP} / \mathrm{ha}$, pupuk dasar Amunium Sulfat $100 \mathrm{kgN} / \mathrm{ha}$, dan $\mathrm{KCl} 70 \mathrm{kgK} / \mathrm{ha}$.

Parameter yang diamati meliputi, kadar bahan kering (BK), protein kasar (PK), fosfat (P), dan serat kasar (SK).

Data yang terkumpul diolah untuk menguji hipotesis statistik dengan prosedur analisis ragam, Uji Wilayah Ganda Sidik ragam.(Steel and Torrie, 1990)

Tabel 1. Data curah hujan

\begin{tabular}{lllllll}
\hline \hline & Maret & April & Mei & Juni & Juli & Agustus \\
\hline Curah hujan & 199 & 314 & 125 & 267 & 133 & 44 \\
urah hujan Maks. & 85 & 104 & 48 & 81 & 81 & 26 \\
\hline
\end{tabular}

Sumber: Data Sekunder BMKG Semarang, 2013.

\section{HASIL DAN PEMBAHASAN}

\section{Kualitas Jerami Sorgum}

Hasil analisis ragam kualitas jerami sorgum disajikan pada tabel 2 berikut: 
Tabel 2. Kualitas Jerami Sorgum

\begin{tabular}{|c|c|c|c|c|c|c|c|c|}
\hline & \multicolumn{2}{|c|}{ Panen 1} & \multirow[b]{2}{*}{$\mathrm{P}$} & \multirow[b]{2}{*}{ SK } & \multicolumn{4}{|c|}{ Panen 2} \\
\hline & $\mathrm{BK}$ & $\mathrm{PK}$ & & & $\mathrm{BK}$ & $\mathrm{PK}$ & $\mathrm{P}$ & SK \\
\hline & & & & ----9 & & & & - \\
\hline Kontrol & $12.80^{\mathrm{c}}$ & 2.72 & $0.217^{\mathrm{d}}$ & 37.07 & 55.99 & 2.58 & $0.069^{\mathrm{cd}}$ & 38.54 \\
\hline SP36 & $16.60^{\mathrm{abc}}$ & 3.72 & $0.325^{\mathrm{b}}$ & 38.39 & 58.86 & 2.41 & $0.050^{\mathrm{d}}$ & 47.80 \\
\hline BP & $17.73^{\mathrm{abc}}$ & 3.16 & $0.557^{\mathrm{b}}$ & 35.86 & 54.28 & 2.83 & $0.069^{\mathrm{cd}}$ & 33.36 \\
\hline Pukan & $15.43^{\mathrm{abc}}$ & 2.81 & $0.544^{\text {bc }}$ & 37.22 & 46.05 & 3.03 & $0.167^{\mathrm{b}}$ & 35.09 \\
\hline Pukan"plus" & $14.50^{\mathrm{abc}}$ & 3.06 & $0.721^{\mathrm{cd}}$ & 34.15 & 58.29 & 2.22 & $0.145^{\mathrm{b}}$ & 40.08 \\
\hline Arang & $13.91^{\mathrm{bc}}$ & 3.17 & $0.356^{\mathrm{dc}}$ & 38.38 & 55.20 & 2.99 & $0.083^{\mathrm{cd}}$ & 48.28 \\
\hline SP36+arang & $18.80^{\mathrm{ab}}$ & 3.37 & $0.537^{\mathrm{bc}}$ & 37.59 & 59.99 & 2.28 & $0.176^{\mathrm{b}}$ & 28.89 \\
\hline $\mathrm{BP}+$ arang & $17.45^{\mathrm{abc}}$ & 3.13 & $0.280^{\mathrm{d}}$ & 38.16 & 57.55 & 2.38 & $0.148^{\mathrm{b}}$ & 37.07 \\
\hline Pukan+arang & $20.13^{\mathrm{a}}$ & 3.23 & $0.966^{\mathrm{a}}$ & 38.65 & 54.82 & 2.90 & $0.124^{\mathrm{cd}}$ & 42.60 \\
\hline Pukan"plus"+arang & $17.38^{\mathrm{abc}}$ & 2.92 & $0.764^{\mathrm{ab}}$ & 35.19 & 57.25 & 2.44 & $0.358^{\mathrm{a}}$ & 36.85 \\
\hline Rataan & 16.47 & 3.13 & 0.527 & 37.07 & 55.83 & 2.61 & 0.138 & 38.86 \\
\hline
\end{tabular}

Keterangan: Huruf yang berbeda pada masing-masing kolom menunjukan pengaruh nyata $(\mathrm{P}<0,05)$. BK: Bahan Kering; PK: Protein Kasar; P: Fosfat; SK: Serat Kasar.

Kadar BK panen 1 (Tabel 2) memberikan pengaruh nyata $(\mathrm{P}<0,05)$. Perlakuan pupuk T8 menghasilkan hasil tertinggi namun perlakuan tersebut tidak mengalami perbedaan pada pemberian pupuk SP36 (16,60\%), pukan, pukan "plus" $(14,50 \%)$ dan BP $(17,73 \%)$. Bahan kering panen 2 (Tabel 2) tidak berbeda nyata $(\mathrm{P}>0,05)$. Kondisi panen 1 dan 2 berbeda musim menjadikan panen 2 lebih tinggi kadar bahan kering dibandingkan panen 1 yang jatuh pada musim penghujan. Berdasarkan Tabel 2 BK panen 1(16.47\%) lebih rendah dibandingkan dengan panen 2 $(55.83 \%)$ diduga periode panen yang terjadi dilakukan pada 2 musim yaitu musim penghujan pada panen 1 dan musim kemarau pada panen 2. Penelitian Amaducci et al (2000) pada penanaman dengan 2 kali defoliasi, defoliasi kedua menghasilkan BK yang lebih tinggi bila dibandingkan BK defoliasi pertama. Musim kemarau kadar bahan kering lebih tinggi disebabkan intensitas cahaya matahari yang meningkatkan respirasi dan transpirasi tanaman (Zecevic, 2007). Intensitas hujan mempengaruhi konsistensi BK tanaman (Wayne, 2012). Kadar bahan kering dipengaruhi beberapa faktor yaitu ketersediaan air, usia tanam, curah hujan, kelembaban, intensitas cahaya matahari (Sitompul dan Guritno, 1995).

Kadar PK panen 1 (Tabel 2) tidak memberikan pengaruh nyata $(\mathrm{P}>0,05)$. Pemberian beraneka pupuk fosfat memberikan efek yang sama terhadap jerami sorgum. Kadar PK pada jerami tidaklah lebih dari $4 \%$. Jerami adalah fase dimana tanaman telah melewati masa generatif. Tanaman pada saat masa generatif semua nutrisi yang terdapat pada batang digunakan untuk pembentukan biji, sehingga kadar PK menjadi rendah (Seseray, 2013). Fase geratif merupakan fase dimana tanaman berbunga, sehingga nutrisi yang terdapat pada batang tanaman di gunakan untuk pembentukan biji sehingga jerami rendah nutrisinya (Sitompul dan Guritno, 1995).

Kadar $\mathrm{P}$ dalam jerami sorgum memberikan hasil yang berbeda nyata $(\mathrm{P}<0,05)$. Pemberian pupuk sumber $\mathrm{P}$ pada beberapa perlakuan baik SP36 dengan pupuk kandang "plus" menghasilkan kadar $\mathrm{P}$ yang sama. Perlakuan T7 yang menggunakan SP36 + arang (38.14\%) tidak berbeda dengan T0 (37.07\%), diduga penggunaan arang pada perlakuan T7 
mampu menyerap $\mathrm{P}$ yang mudah larut dengan air, tetapi pada perlakuan dengan pupuk kandang "plus" yang memiliki sifat lambat tersedia arang tidak mampu menjerap P yang larut dalam asam. Aplikasi bahan organik memberikan kelarutan pada fosfat alam (Sutriadi et al,. 2005). Arang merupakan padatan yang dapat mengabsorbsi senyawa gas atau padatan tergantung besar dan jumlah pori (Harsanti et al., 2012). Pemberian $P$ alam pada tabel 1 tidak memberikan perbedaan nyata ( $\mathrm{P}>0,05 \%)$, diduga kondisi tanah yang masam mengakibatkan $\mathrm{P}$ alam menjadi larut air. Kelarutan $\mathrm{P}$ alam dapat diakibatkan melalui asam-asam organik (Tuherkih dan Dariah, 2009).

SK pada panen 1 (Tabel 2) tidak berbeda nyata $(\mathrm{P}>0,05)$. Penggunaan pupuk sumber $\mathrm{P}$ pada sorgum menghasilkan serat kasar yang sama. Jerami merupakan hasil sisa setelah diambil produksi biji atau setelah fase generatif. Fase generatif merupakan fase dimana tanaman berbunga, sehingga nutrisi yang terdapat pada batang tanaman di gunakan untuk pembentukan biji sehingga jerami rendah nutrisinya (Sitompul dan Guritno, 1995).

\section{KESIMPULAN DAN SARAN}

\section{Kesimpulan}

Perlakuan SP36, BP, pukan, pukan"plus" dengan atau tanpa arang tidak mampu meningkatkan kadar BK, PK dan SK, tetapi mampu meningkatkan kadar fosfat jerami sorgum.

\section{Saran}

Perlu pengkajian lebih mendalam berkaitan dengan pemberian SP36, BP, pupuk kandang dengan arang agar dapat mengoptimalkan kembali berat kering, protein kasar dan serat kasarnya

\section{DAFTAR PUSTAKA}

Amaducci, A., M. T. Amaducci, R. Benati, and G. Venturi. 2000. "Crop yield and quality parameters of four annual fibre crops (hemp, kenaf, maize and sorghum) in the North of Italy." Elsevaier Industrial Crops and Products, 11 179-186.

Ari, N. N. M. 2007. "Pengaruh Jenis Pupuk Kandang dan Jarak Tanam terhadap Pertumbuhan Gulma dan Hasil Jagung Manis." J. Agritrop, 26 (4): 153-159.

Harsanti, E. S., A. Nugraha, Ardiwinata, S. Wahyuni, Indratin, A. Hidayah, dan E. Sulaeman. 2012. "Pengembangan Teknologi Pelapisan Urea dengan Arang Aktif yang diperkaya Mikroba Pendegradasi POPs yang Mampu meningkatkan Efisiensi Pemupukan $>50 \%$ dan Menurunkan Redisu Insektisida di Bawah Ambang Aman pada Pertanaman Sayuran." Laporan Penelitian. Program Insentif Riset Badan Penelitian dan Pengembangan Pertanian.

Hartatik, W. 2011. "Fosfat Alam Sumber Pupuk P yang Murah Fosfat." Warta Penelitian dan Pengembangan Pertanian, 33 (1): 10-12.

Lempang, W. Syafii dan G. Pari. 2011. "Struktur dan Komponen Arang Aktif Tempurung Kemiri." $J$. Penelitian Hasil Hutan, 29 (3): 278294.

Pabbage, M. S. 2005. "Hubungan antara Faktor Fisik dan Kimia Biji Sorgum 
dengan Pertumbuhan Populasi Serangga Hama Gudang." Prosiding Seminar Nasional Jagung, Makasar, 29-30 September 2005: 575-580.

Rostiwati. T., Y. Heryati, dan Gusmailina. 2008. "Upaya Peningkatan Kandungan Hara Media Melalui Campuran Top Soil dan Arang Aktif untuk Pertumbuhan Semai Eucalyptus urophylla." Mitra Hutan Tanaman, 3 (1): 21-32.

Samanhudi. 2010. "Pengujian Cepat Ketahanan Tanaman Sorgum Manis Terhadap Cekaman Kekeringan." $J$. Agrosains, 12 (1): 9-13.

Seseray, D. Y., B. Santoso, dan M. M. Lekitoo. 2013. "Produksi Rumput Gajah (Pennisetum purpureum) yang Diberi Pupuk N, P dan K dengan Dosis 0, 50 dan 100\% pada Devoliasi Hari ke-45." Sains Peternakan Vol. 11 (1): 49-55.

Shanti. R. 2009. "Pengaruh Pemberian Pupuk Kandang Ayam dan Pengolahan Lahan terhadap Hasil Kacang Tanah (Arachishypogea L)." J. Agrifor, 3: 40-47.

Sitompul, S. M. dan B. Guritno. 1995. Analisis Pertumbuhan Tanaman. Yogyakarta: Universitas Gajahmada press.

Soelaeman, Y. 2007. "Efisiensi Pupuk Kandang dalam Meningkatkan Ketersedian Fosfat, Pertumbuhan dan Hasil Padi dan Jagung pada Lahan Kering dan Masam." $J$. Tanah. Trop., 13(1): 41-47.

Soeranto, H., Sihono, dan Parno. 1996. "Perbaikan Genetik Sorgum melalui Program Pemuliaan Tanaman." Makalah dalam Fokus Grup Diskusi
"Prospek Sorgum untuk Mendukung Ketahanan Pangan dan Energi”. Menristek Batan. Serpong, 5 Sept. Hlm: 15-31.

Sutriadi, M. T., R. Hidayat, S. Rochayato, dan D. Setyorini. 2005. "Ameliorasi Lahan dengan Fosfat Alam untuk Perbaikan Kesuburan Tanah Kering Masam Typic Hapludox di Kalimantan Selatan. Halaman 143155." Prosiding Seminar Nasional Inovasi Sumber daya Tanah dan Iklim. Buku II. Bogor, 14-15 September 2004. Bogor: Pusat Penelitian dan Pengembangan Tanah dan Agroklimat.

Tuherkih, E. dan A. Darian. 2009. "Pemupukan P-alam terhadap Tanaman Jagung pada Inceptisols." Prosiding Seminar dan Lokakarya Nasional Inovasi Sumber Daya Lahan. Bogor, 24-25 November 2009, 277-287.

Wayne. K., I. Coblentz, and Richard E. Muck. 2012. "Effects of Rain Damage on Wilting Forages." Focus on Forage, Vol 15: No. 7.

Zecevic, V., D. Kneževic, and D. Micanovic. 2007. Seed Dry Matter Accumulation of Wheat In Different Matu. 